Jurnal Ekonomi dan Bisnis, Vol. 9 No. 1 September 2018

ISSN : 2503-4413, Hal 18 - 36

\title{
ANALISIS FAKTOR-FAKTOR FUNDAMENTAL YANG BERPENGARUH TERHADAP RETURN SAHAM SYARIAH PADA PERUSAHAAN YANG TERGABUNG DALAM JAKARTA ISLAMIC INDEX (JII)
}

\author{
Fitri \\ Akuntansi, STIE DR KHEZ MUTTAQIEN PURWAKARTA \\ Fitriwardana30@gmail.com
}

\begin{abstract}
The development of the sharia capital market in Indonesia until 2016 shows that Islamic stock shares do not yet have optimal and consistent performance in terms of the returns given. Fundamental analysis is a study that studies matters relating to the finances of a business with a view to better understanding the basic nature and operational characteristics of public companies that issue shares. Accounting information or company financial statements can be used as a factor of fundamental analysis based on real data that is useful for evaluating and projecting the value of a stock. The purpose of this study was to determine the effect of return on assets (ROA), Debt to Equity Ratio (DER), Current Ratio (CR), Earning per share (EPS), Total asset turn over (TATO) on Islamic stock returns. The research method used is descriptive verification. The unit of analysis in this study is Islamic stocks that are members of the Jakarta Islamic Index (JII). Statistical test analysis in this study using multiple linear regression analysis, $t$ test and $F$ test. The results showed that the variables ROA, CR, EPS and TATO have a positive and significant effect on Islamic stock returns, but the DER variable does not have a significant effect on stock returns. sharia.
\end{abstract}

Keywords: return on asset (ROA), Debt to Equity Ratio (DER), Current Ratio (CR), Earning per share (EPS), Total assets turn over (TATO),

\section{PENDAHULUAN}

Investasi di pasar modal merupakan salah satu cara yang ditempuh sebuah perusahaan untuk memperoleh peningkatan laba. Investasi merupakan salah satu kegiatan muamalah yang sangat di anjurkan karena dengan investasi harta yang dimiliki menjadi produktif dan dapat memberikan manfaat bagi sesama manusia.

Pasar modal syariah dimulai sejak munculnya instrumen pasar modal yang menggunakan prinsip syariah pada tanggal 14 maret 2003. Menurut Boediono ada beberapa alasan yang mendasari pentinganya keberadaan sebuah pasar modal yang berbasis syariah, pertama pakar ekonomi islam telah mampu membuat surat surat berharga yang berlandaskan syariah sebagai alternatif bagi surat surat berharga yang beredar dan tidak sesuai dengan hukum islam dan yang kedua memberikan tempat bagi lembaga keuangan islam dan ilmu ilmu yang berkaitan dengan teknik perdagangan, sekaligus aktifitas yang sesuai dengan syariah (Fajar Kurnia Imam,2017).

$$
\text { Jakarta Islamic Index }
$$

merupakan pengelompokan saham saham 30 emiten yang dipandang paling mendekati kriteria syariah. Perkembangan pasar modal syariah di Indonesia hingga tahun 2016 menunjukan bahwa saham saham syariah belum memiliki kinerja yang optimal dan konsisten dalam hal return yang diberikan. Berikut perkembangan return saham emiten syariah yang termasuk pada kelompok emiten Jakarta Islamic Index : 
Grafik 1.1

Perkembangan Return Saham Jakarta

Islamic Index

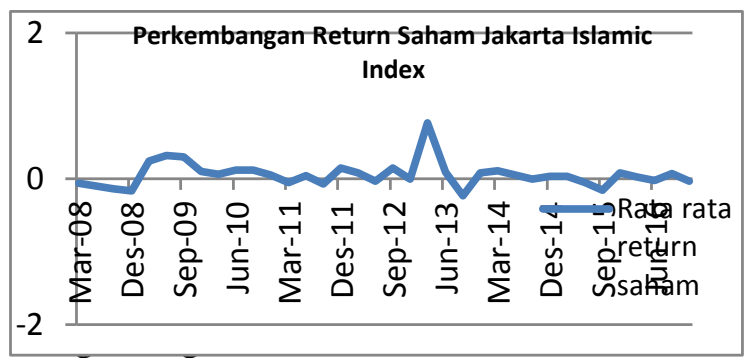

yang ketat dan didukung oleh data yang akurat. Ada dua informasi yang dibutuhkan investor di pasar modal dalam pembuatan kebijakan keputusan informasinya adalah tentang faktor fundamental dan faktor teknikal.

Analisis fundamental merupakan suatu studi yang mempelajari hal hal yang berhubungan dengan keuangan suatu bisnis dengan maksud untuk lebih memahani sifat dasar dan karakteristik operasional dari perusahaan publik yang menerbitkan saham (Robert Ang,1997). Data yang biasanya digunakan untuk melakukan analisis fundamental adalah rasio margin laba (profit margin), rasio imbal hasil atau pengembalian ekuitas, pertumbuhan penjualan, laba, pendapatan dan data data keuangan lainnya untuk menilai kinerja perusahaan dan meramalkan pertumbuhan perusahaan di masa depan (Michell Suharli,2001). Kinerja keuangan yang di tuangkan dalam bentuk laporan keuangan dan di ukur dalam bentuk rasio yang di antaranya berupa rasio profitabilitas, solvabilitas, likuiditas, dan rasio lainnya dapat digunakan untuk menilai suatu saham (Murtanto dan Harkivent,2000)

Rasio profitabilitas yang digunakan dalam penelitian ini adalah Return On assets (ROA). ROA dapat digunakan untuk mengetahui kinerja perusahaan berdasarkan kemampuannya mendayagunakan seluruh asset yang dimiliki. Penelitian yang dilakukan oleh Yeye Susilowati dan Tri Turyanto (2011), Chuzaimah dan Nur Amalia (2014) menunjukan hasil bahwa ROA tidak berpengaruh terhadap return saham. Hasil yang berbeda di peroleh dari penelitian Meri Arisandi (2014), Bambang
Sudarsono dan bambang Sudiyatno (2016) dan Juanita Bias (2016) menunjukan hasil bahwa ROA berpengaruh signifikan terhadap return saham.

Debt to Equity Ratio (DER) merupakan rasio solvabilitas yang menggambarkan kemampuan modal perusahaan untuk dijadikan jaminan atas semua kewajiban yang dimiliki perusahaan (Kamarudin ,2004) . DER yang tinggi menunjukan hutang yang dimiki perusahaan semakin besar dibandingkan dengan modalnya. Hasil penelitian Yeye susilowati dan Tri Turyanto (2011), Sugiarti Surahcman dan Siti Aisyah (2015), Ganesh (2012) menunjukan hasil penelitian bahwa DER berpengaruh terhadap return saham. Penelitian yang dilakukan oleh Meri Arisandi (2014), Hekikus Manao (2000), Gulnur Murodonglu (2008) menunjukan bahwa DER tidak berpengaruh terhadap return saham.

Current ratio (CR) merupakan salah satu rasio likuiditas, rasio ini digunakan untuk mengukur kemampuan perusahaan dalam memenuhi kewajiban jangka pendek perusahaan ( Syamsudin,2004). Semakin besar nilai current ratio yang dimiliki perusahaan menunjukan besarnya perusahaan dalam memenuhi kebutuhan operasionalnya dan untuk menjaga performance kinerja perusahaan. Hasil penelitian yang dilakukan oleh Ulupui (2008), Ganesh (2012) dan Sabalno (2010) menunjukan bahwa CR berpengaruh signifikan terhadap return saham. Berbeda dengan hasil penelitian yang dilakukan oleh Meri Arisandi (2014) yang menunjukan bahwa current ratio tidak berpengaruh terhadap return saham.

Earning per share (EPS) merupakan rasio pasar yang bisa digunakan oleh investor untuk menilai kinerja perusahaan, rasio ini menggambarkan seberapa besar return yang diperoleh investor atas per lembar saham yang dimilikinya (Gantyowati dan Arwanta,2004). Hasil penelitian yang dilalukan oleh Eljelly dan Algurair (2001), menunjukan bahwa Earning per share (EPS) merupakan variabel yang mempengaruhi return saham. 
Total asset turn over (TATO) merupakan rasio aktifitas yang menunjukan sejauh mana perusahaan dapat mengoptimalkan aktivanya untuk memperoleh laba, nilai total asset tur over yang tinggi menunjukan perusahaan dapat mengoptimalkan kinerja aktivanya (Hanafi,2004). Hasil penelitian Ulupui (2009), Chuzimah dan Nur Amalia (2014) menunjukan bahwa secara parsial TATO tidak berpengaruh terhadap return saham. Hasil berbeda ditunjukan oleh hasil penelitian Aisyah Husna,Muhammad Syamsun dan Tb Nur Maulana (2016) yang menunjukan TATO berpengaruh terhadap return saham.

Berdasarkan uraian di atas, penelitian ini memfokuskan tentang faktor faktor funfamental yang mempengaruhi return saham terhadap perusahaan yang terdaftar di Jakarta Islamic Index, oleh karena itu penulis tertarik untuk menulis tesis dengan judul “ Analisis Faktor-Faktor Fundamental Terhadap Return Saham Syariah Pada Perusahaan Yang Tergabung Dalam Jakarta Islamic Index (JII) ".

\section{KAJIAN PUSTAKA \\ Return On assets (ROA)}

Return On assets (ROA) merupakan rasio yang membandingkan antara laba bersih terhadap total aktiva (Husnan,2001). Rumus yang digunakan dalam perhitungan Return On assets (ROA) dalam penelitian ini adalah perhitungan Return On assets (ROA) yang dijelaskan oleh Husnan (2001) yaitu membandingkan antara laba bersih setelah pajak terhadap total aktiva.

\section{Debt to Equity Ratio (DER)}

Debt to Equity Ratio (DER) merupakan rasio pengukur leverage perusahaan (Gitman dan Joehnk,1996). Semakin tinggi Debt to Equity Ratio (DER) menunjukan komposisi total utang (jangka pendek dan jangka panjang) semakin besar dibanding dengan total modal sendiri, sehingga dampaknya adalah semakin besar beban perusahaan tehadap pihak luar (Ang, 1997).

Rumus yang digunakan dalam perhitungan Debt to Equity Ratio (DER) dalam penelitian ini adalah perhitungan Debt to Equity Ratio (DER) yang dijelaskan oleh Gitman dan Joehnk (1996) yaitu membandingkan antara total hutang terhadap ekuitas.

\section{Current Ratio (CR)}

Current Ratio merupakan rasio yang digunakan untuk mengukur kemampuan perusahaan dalam membayar kewajiban jangka pendek atau hutang yang segera akan jatuh tempo pada saat ditagih secara keseluruhan (Kasmir, 2012). Rumus yang digunakan dalam perhitungan Current ratio $(C R)$ dalam penelitian ini adalah perhitungan Current ratio (CR) yang dijelaskan oleh Horne dan Wachowicz (2007) yaitu membandingkan antara aktiva lancar terhadap kewajiban jangka pendeknya.

\section{Earning per share (EPS)}

Tandelilin (2007) mendefinisikan Earning per share (EPS) sebagai perbandingan antara jumlah laba bersih dengan jumlah saham yang beredar. Rumus yang digunakan dalam perhitungan Earning per share (EPS) dalam penelitian ini adalah perhitungan Earning per share (EPS) yang dijelaskan oleh Tandelilin (2007) yaitu membandingkan antara laba bersih setelah bunga dan pajak terhadap jumlah saham yang beredar.

\section{Total asset turn over (TATO)}

Menurut Brigham (2006) Total asset turn over (TATO) adalah rasio aktifitas yang digunakan untuk mengukur seberapa besar efektifitas perusahaan dalam menggunakan sumber daya asset, rasio ini adalah rasio antara penjualan dengan total aktiva yang mengukur efisiensi penggunaan aktiva secara keseluruhan, apabila rasio rendah mengundikasikan bahwa perusahaan tidak beroperasi pada volume yang memadai bagi kapasitas investasinya. Rumus yang digunakan dalam perhitungan Total asset turn over (TATO) dalam penelitian ini adalah perhitungan Total asset turn over (TATO) yang dijelaskan oleh Van Horne dan Wachowicz (2007) yaitu membandingkan antara penjualan terhadap total assets. 


\section{Return Saham}

Return saham adalah tingkat keuntungan yang dinikmati oleh pemodal atas suatu investasi saham yang telah dilakukannya (Ang, 1997). Investasi jangka pendek maupun jangka panjang memiliki tujuan utama untuk memperoleh keuntungan yang disebut dengan return, baik langsung maupun tidak langsung (Ang, 1997). Return saham juga merupakan selisih dari harga investasi sekarang relatif dengan harga periode lalu (Jogiyanto, 2007).

\section{KERANGKA PEMIKIRAN DAN HIPOTESIS}

Kerangka pemikiran penelitian dapat dilihat dalam Gambar 2.1 berikut :

Gambar 2.1 Kerangka Pemikiran

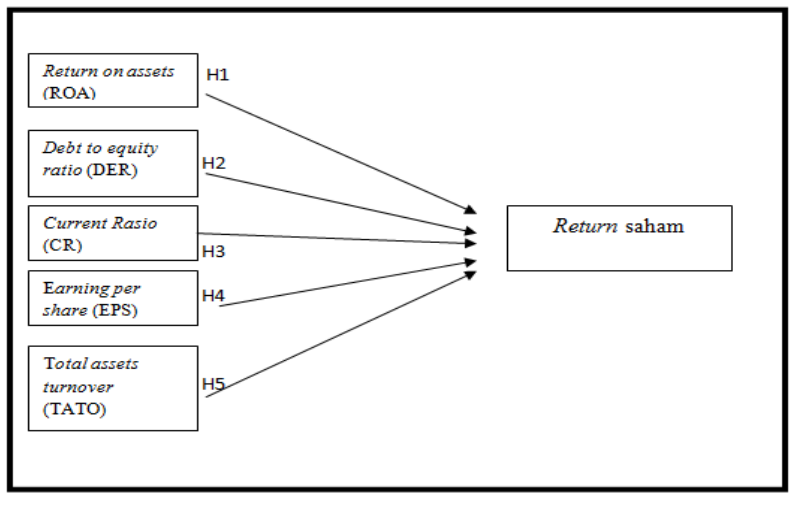

Hipotesis penelitian adalah sebagai berikut. $\mathrm{H}_{1}$ : Return on assets (ROA) berpengaruh positif terhadap return saham syariah yang tergabung dalam Jakarta Islamic Index (JII). $\mathrm{H}_{2}$ : Debt to equity ratio (DER) berpengaruh negatif terhadap return saham syariah yang tergabung dalam Jakarta Islamic Index (JII). $\mathrm{H}_{3}$ : Current Rasio (CR) berpengaruh positif terhadap return saham syariah yang tergabung dalam Jakarta Islamic Index (JII). $\mathrm{H}_{4}$ : Earning per share (EPS) berpengaruh positif terhadap return saham syariah yang tergabung dalam Jakarta Islamic Index (JII). $\mathrm{H}_{5}$ : Total assets turnover (TATO) berpengaruh positif terhadap return saham syariah yang tergabung dalam Jakarta Islamic Index (JII).

$\mathrm{H}_{6}$ : Return on assets (ROA), Debt to equity ratio (DER), Current Rasio (CR), Earning per share (EPS), dan Total assets turnover
(TATO) berpengaruh terhadap return saham syariah yang tergabung dalam Jakarta Islamic Index (JII).

\section{METODE PENELITIAN}

Penelitian ini merupakan jenis penelitian kausal eksplanatori dengan pendekatan kuantitatif. Menurut Sugiyono (2010) penelitian eksplanatori adalah penelitian yang menjelaskan hubungan kausal antara variabel variabel yang mempengaruhi hipotesis. Menurut Emzir (2009) pendekatan Kuantitatif adalah suatu pendekatan penelitian yang secara primer menggunakan paradigma postpositivist dalam mengembangkan ilmu pengetahuan. Anggota populasi dalam penelitian ini adalah seluruh perusahaan yang memiliki saham syariah yang tergabung dalam Jakarta Islamic Index (JII) periode 2008 hingga 2016. Penarikan sampel penelitian dilakukan dengan menggunakan metode purposive sampling dengan dasar ktiteria yang ditetapkan dalam penelitian ini adalah sebagai berikut :

Perusahaan yang sudah go public dan terdaftar di Bursa Efek Indonesia.

Laporan keuangan perusahaan berakhir 31 desember.

Perusahaan secara aktif sahamnya diperdagangkan selama periode penelitian

d. Perusahaan masuk pada daftar perusahaan yang tergabung dalam Jakarta Islamic Index (JII) periode 2009 hingga 2016.

Sumber data yang digunakan dalam penelitian ini adalah data sekunder. Teknik pengumpulan data menggunakan studi kepustakaan serta studi lapangan yang terdiri dari dokumentasi.

Untuk menguji semua hipotesa dalam penelitian ini, digunakan analisis regresi yang perhitungannya memakai program Eviews. Model persamaan Analisis Regresi Linier Berganda dalam penelitian ini dapat ditulis sebagai berikut. 


$$
\mathbf{Y}=\alpha+\boldsymbol{\beta}_{1} \mathbf{X}_{1}+\underset{\mathbf{\beta}_{2}}{\mathbf{X}_{5}+\varepsilon}
$$

Keterangan:

$\mathrm{Y}=$ Return saham

$\alpha \quad=$ Intercept

$\varepsilon \quad=$ Error term $/$ Variable residual

$\beta_{1}-\beta_{5}=$ Koefisien regresi

$\mathrm{X}_{1} \quad=$ Return On assets (ROA)

$\mathrm{X}_{2} \quad=$ Debt to Equity Ratio (DER)

$\mathrm{X}_{3}=$ Current ratio (CR)

$\mathrm{X}_{4} \quad=$ Earning per share (EPS)

$\mathrm{X}_{5} \quad=$ Earning per share (EPS)

Untuk menentukan model terbaik yang dapat digunakan, peneliti harus melakukan uji pemilihan teknik estimasi regresi. Terdapat dua cara dalam melakukan pemilihan teknik estimasi untuk menentukan teknik yang paling tepat dalam mengestimasi parameter data panel. Pertama, uji Chow (Likelihood Ratio) digunakan untuk memilih antara metode Common Effect atau Fixed Effect. Kedua, uji Hausman yang digunakan untuk memilih antara metode Fixed Effect atau metode Random Effect (Baltagi,2005). Penjelasan Mengenai uji pemilihan teknik estimasi yang digunakan dalam analisis data panel adalah sebagai berikut :

\section{Uji Chow}

Chow test merupakan uji untuk membandingkan model common effect dengan fixed effect (Widarjono, 2009). Chow test dalam penelitian ini menggunakan program Eviews. Hipotesis yang dibentuk dalam Chow test adalah sebagai berikut :

H0 : Common Effect Model (restricted)

H1: Fixed Effect Model (unrestricted) Apabila dalam hasil uji Chownilai F-statistik > F-tabel atau probabilitasnya <taraf signifikansi, maka HOditolak dan Fixed Effect Model yang baik digunakan. Tetapi, jika hasil uji Chow menunjukkan nilai F -statistik< F-tabel atau probabilitasnya $>$ taraf signifikansi, maka H0diterima dan Common Effect Model yang digunakan (Gujarati dan Porter, 2013)

\section{Uji Hausman}

Uji Hausman dilakukan untuk menentukan model estimasi data panel yang paling baik dan tepat antara Fixed Effect Model atau Random Effect Model. Menurut Judge dalam Gujarati dan Porter (2012), Uji Hausman membandingkan antara nilai statistic Hausman dengan nilai tabel distribusi Chi-square dengan degre of freedom sejumlah variabel independen. Bila nilai statistik Hausman > Chi-Squaredan nilai probabilitas $<\alpha$ (nilai kritis) maka $\mathrm{H} 0$ ditolak dan pendekatan Fixed Effect Model yang dipilih.Sedangkan, bilanilai statistik Hausman < Chi-Squaredan nilai probabilitas $>\alpha$ (nilai kritis) maka H0diterima dan pendekatan Random Effect Model yang dipilih.Statistik uji Hausman tersebut mengikuti distribusi statistik chi-square dengan degree of freedom sebanyak $k$ dimana $\mathrm{k}$ adalah jumlah variabel independen (Widarjono, 2013).

\section{Uji Lagrange Multiplier (LM).}

Lagrange Multiplier (LM) adalah uji untuk mengetahui apakah model Random Effect atau model Common Effect (OLS) yang paling tepat digunakan. Uji signifikasi Random Effect ini dikembangkan oleh Breusch Pagan. Metode Breusch Pagan untuk uji signifikasi Random Effect didasarkan pada nilai residual dari metode OLS. Uji LM ini didasarkan pada distribusi chi-squares dengan degree of freedom sebesar jumlah variabel independen. Jika nilai LM statistik lebih besar dari nilai kritis statistik chi-squares maka kita menolak hipotesis nul, yang artinya estimasi yang tepat untuk model regresi data panel adalah metode Random Effect dari pada metode Common Effect. Sebaliknya jika nilai LM statistik lebih kecil dari nilai statistik chisquares sebagai nilai kritis, maka kita menerima hipotesis nul, yang artinya estimasi yang digunakan dalam regresi data panel adalah metode Common Effect bukan metode Random Effect (Widarjono, 2009). Uji LM dipakai manakala pada uji Chow menunjukan model yang dipakai adalah Common Effect Model, sedangkan pada uji Hausman menunjukan model yang paling 
tepat adalah Random Effect Model. Maka diperlukan uji LM sebagai tahap akhir untuk menentukan model Common Effect atau Random Effect yang paling tepat (Widarjono, 2009).

Alat analisa yang digunakan adalah analisis regresi linier berganda dan data penelitian yang digunakan adalah data sekunder, maka untuk memenuhi syarat yang ditentukan sehingga penggunaan model regresi linier berganda perlu dilakukan pengujian atas beberapa asumsi klasik. Uji asumsi klasik yang digunakan yaitu uji normalitas,multikolinearitas, heteroskedastisitas dan autokorelasi.. Apabila terjadi penyimpangan asumsi klasik maka dapat menggunakan pengujian statistik non parametrik. Sedangkan,statistik parametrik digunakan untuk pengujian data apabila data variabel terbebas dari multikolinearitas, autokorelasi, dan heterokedastisitas, serta data harus berdistribusi normal. Penjelasan mengenai hal tersebut secara rinci dapat dijelaskan sebagai berikut:

\section{Uji Normalitas}

Menurut Gujarati dan Porter (2013) uji normalitas mempunyai tujuan untuk menguji apakah dalam model regresi variabel pengganggu atau residual memiliki distribusi normal atau tidak.Selain itu,dengan uji normalitas Kita dapat mampu menggunakan hasil pengujian statistik $t$ dan $\mathrm{F}$ karena mengasumsikan nilai residual mengikuti distribusi normal. Apabila asumsi ini dilanggar maka uji statistik menjadi tidak berlaku.Terdapat beberapa metode untuk mengetahui normal atau tidaknya distribusi residual antara lain Jarque-Bera (J-B) Test dan metode grafik. (Gujarati dan Porter, 2013).

\section{Uji Multikolinearitas}

Menurut Ghozali (2001) uji ini bertujuan menguji apakah pada model regresi ditemukan adanya korelasi antar variabel independen. Pada model regresi yang baik seharusnya antar variabel independen tidak terjadi kolerasi. Untuk mendeteksi ada tidaknya multikoliniearitas dalam model regresi dapat dilihat dari tolerance value atau variance inflation factor (VIF).

\section{Uji Heteroskedastitas}

Pengujian ini dilakukan untuk menguji apakah dalam sebuah model regresi terjadi ketidaksamaan varians dari residual suatu pengamatan ke pengamatan yang lain (Priyatno, 2010). Jika varian dari residualnya tetap disebut homoskedastisitas, sedangkan jika varians berbeda maka disebut heteroskedastisitas. Model yang baik tidak terdapat heterokedastisitas, dengan kata lain bila terjadi heterokedastisitas maka model tersebut kurang efisien. Penelitian ini menggunakan Uji Glejser untuk melihat adanya heterokedastisitas.

\section{Uji Autokorelasi}

Uji autokorelasi bertujuan untuk menguji apakah dalam suatu model regresi linear ada korelasi antara kesalahan penggangu pada periode $t$ dengan kesalahan periode $\mathrm{t}-1$ (sebelumnya). Jika terjadi korelasi maka dinamakan ada problem autokorelasi. Model regresi yang baik adalah yang bebas autokorelasi. Untuk mendeteksi autokorelasi, dapat dilakukan uji statistik melalui uji Durbin-Watson (DWtest) (Ghozali, 2001).

Setelah mendapatkan model penelitian yang baik, maka dilakukan pengujian terhadap hipotesis penelitian ini. Untuk menguji hipotesis dilakukan dengan pengujian variabel secara parsial dan secara simultan sebagai berikut :

\section{Analisis Koefisien Determinasi (R2)}

Koefisien determinasi (R2) digunakan untuk mengukur seberapa jauh kemampuan model dalam menerangkan variasi variabel dependen. Koefisien determinasi dapat dicari dengan rumus (Gujarati, 1999):

Nilai koefisien determinansi adalah antara 0 dan 1. Nilai R2 yang kecil berarti kemampuan variabel-variabel independen dalam menjelaskan variasi variabel dependen amat terbatas (Ghozali, 2005). Nilai yang mendekati 1 (satu) berarti variabel-variabel independen memberikan hampir semua informasi yang dibutuhkan untuk memprediksi variasi variabel depende 
Uji F

Uji $F$ digunakan untuk menguji signifikansi pengaruh Return On assets (ROA), Debt to Equity Ratio (DER), Current ratio (CR), Earning per share (EPS), dan Total Assets Turn Over (TATO) terhadap Return saham secara simultan.

\section{Pengujian Hipotesis (Uji t)}

Pengujian secara parsial menggunakan uji t (pengujian signifikansi secara parsial). Pengujian secara parsial ini dimaksudkan untuk melihat seberapa jauh pengaruh satu variabel independen secara individual dalam menerangkan variasi variabel dependen (Gujarati, 1999).

\section{HASIL DAN PEMBAHASAN Perkembangan Return on Asset (ROA) Saham Syariah}

Return On Assets (ROA) adalah salah satu rasio profitabilitas yang penting digunakan untuk mengetahui sejauhmana kemampuan aktiva yang di miliki perusahaan dapat menghasilkan keuntungan (Tandelilin, 2007). Semakin besar Return On assets (ROA) menunjukan kinerja perusahaan semakin baik. Pengelolaan aktiva perusahaan secara efektif akan menghasilkan laba bagi perusahaan, sehingga dengan besarnya nilai Return On assets (ROA) akan membuat investor percaya bahwa operasional perusahaan telah di kelola dengan baik. Keadaan ini akan di respon positif oleh investor sehingga permintaan saham perusahaan meningkat dan dapat menaikkan harga saham sehingga berdampak pada return yang meningkat pula (Husnan, 1998). Grafik 4.1 berikut menggambarkan perkembangan Return On assets (ROA) saham syariah selama tahun $2009-2016$.

\section{Grafik 4.1}

Perkembangan Return On Assets Saham Syariah yang terdaftar di Jakarta Islamic Index Periode 2009-2016.

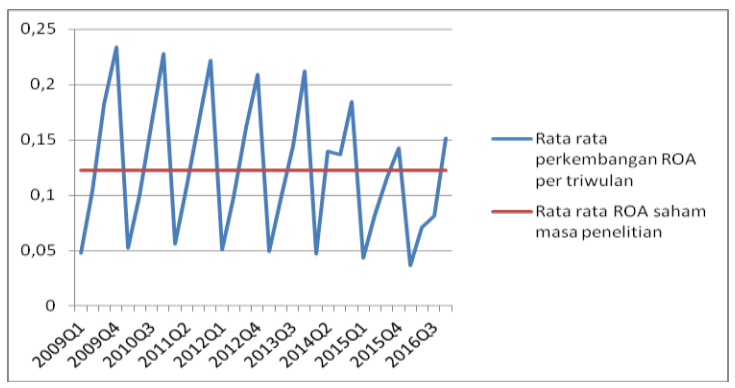

Sumber : Laporan Keuangan Publikasi, Data Diolah (2017)

Grafik 4.1 diperoleh informasi bahwa rata-rata ROA saham syariah adalah sebesar 0.12. Posisi ROA tertinggi dimiliki oleh emiten UNVR berada pada Triwulan IV Tahun 2009 sebesar 0,56 dan terendah dimiliki oleh emiten UNTR pada Triwulan I Tahun 2016 sebesar 0,01. Pertumbuhan profitabilitas saham syariah cenderung berfluktuasi. Menurut Kasmir (2008) standar rata rata industri untuk rasio Return On Assets (ROA) adalah 0,3 atau 30\%, sehingga jika dibandingkan dengan standar ini maka nilai rata rata rasio Return On Assets (ROA) saham syariah yang terdaftar di Jakarta Islamic Index yang nilainya 0.12 masih di bawah standar yang di tetapkan. Perubahan Return On Assets (ROA) menurut Gill and Chatton (2006) di di bentuk oleh penyusutan pabrik dalam jumlah besar, assets intangible (bukan fisik, seperti hak paten) atau pendapatan dan biaya yang tidak biasa.

\section{Perkembangan Debt to Equity Ratio (DER) Saham Syariah}

Debt to Equity Ratio (DER) menggambarkan perbandingan hutang dengan equitas dalam pendanaan dan menunjukan kemampuan modal sendiri perusahaan tersebut untuk memenuhi kewajibannya (Sutrisno, 2012). Grafik 4.2 berikut menggambarkan perkembangan DER saham syariah selama tahun 2009 2016.

Grafik 4.2

Perkembangan Debt to Equity Ratio (DER) Saham Syariah yang terdaftar di Jakarta Islamic Index Periode 2009-2016

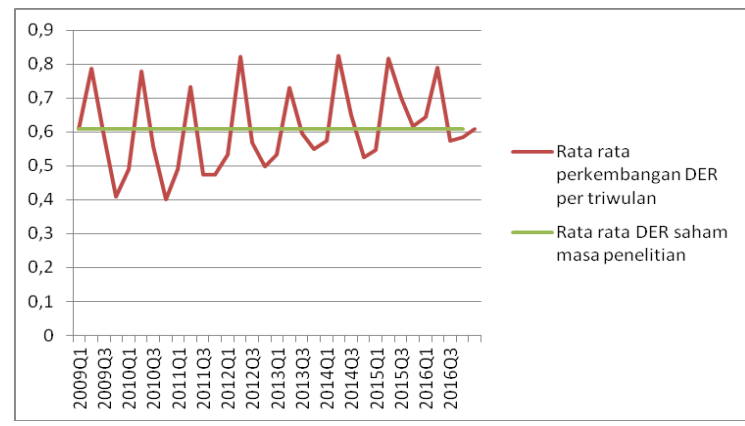


Sumber : Laporan Keuangan Publikasi, Data Diolah (2017)

Grafik 4.2 diperoleh informasi bahwa rata-rata DER saham syariah tahun 2009-2016 adalah sebesar 0,61. DER terendah dimiliki oleh emiten INTP berada pada triwulan IV tahun 2016 sebesar 0,004 dan DER terbesar dimiliki oleh emiten UNVR pada triwulan II tahun 2016 sebesar 2,87. Perkembangan DER emiten saham syariah selama tahun 2009-2016 cenderung berfluktuasi. Penetapan standar besaran nilai ratio Debt to Equity Ratio (DER) didasarkan pada Peraturan Menteri Keuangan No. 169/PMK.010/2015 Pasal 1 ayat 1 tentang Penentuan Besarnya Perbandingan Antara Utang dan Modal Perusahaan adalah sebesar 4:1 atau 0,8 (80\%). Rata rata nilai rasio Debt to Equity Ratio (DER) pada Saham Syariah yang terdaftar di Jakarta Islamic Index 0,61, sehingga jika dibandingkan dengan standar tersebut nilai rasio Debt to Equity Ratio (DER) saham syariah bisa dikatakan nilai rasio Debt to Equity Ratio (DER) nya masih baik. Menurut Gill and Chatton (2006) faktor faktor pembentuk yang menyebabkan berfluktuasinya Debt to Equity Ratio (DER) adalah kenaikan atau penurunan hutang, kenaikan atau penurunan modal sendiri, hutang atau modal bernilai tetap, hutang meningkat lebih tinggi dibandingkan dengan modal sendiri atau sebaliknya.

\section{Perkembangan Current Ratio (CR)} Saham Syariah

Current Ratio (CR) merupakan rasio

yang digunakan untuk mengukur kemampuan perusahaan dalam membayar kewajiban jangka pendek atau hutang yang segera akan jatuh tempo pada saat ditagih secara keseluruhan (Kasmir, 2012). Grafik 4.3 berikut menggambarkan perkembangan Current Ratio (CR) saham syariah selama tahun 2009 - 2016.

\section{Grafik 4.3}

Perkembangan Current Ratio (CR)

Saham Syariah yang terdaftar di Jakarta Islamic Index Periode 2009-2016.

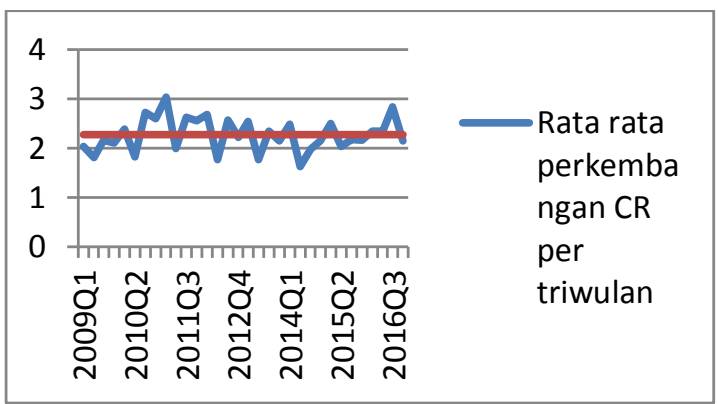

Sumber : Laporan Keuangan

Publikasi, Data Diolah (2017)

Grafik 4.3 diperoleh informasi bahwa rata-rata $\mathrm{CR}$ saham syariah tahun 2009-2016 adalah sebesar 2,27. CR terendah dimiliki oleh emiten SMGR berada pada triwulan III tahun 2014 sebesar 0,21 dan CR terbesar dimiliki oleh emiten INTP pada triwulan I tahun 2011 sebesar 8,38. Perkembangan CR emiten saham syariah selama tahun 2009-2016 cenderung berfluktuasi.

Perkembangan naik turunnya nilai Current Ratio $(C R)$ dibentuk oleh perubahan kenaikan dan penurunan jumlah aktiva dan hutang yang dimiliki oleh masing masing perusahaan. Menurut Kasmir (2008) standar nilai rasio Current Ratio (CR) dikatakan baik jika nilainya mencapai 2 atau 200\%. Rata-rata Current Ratio (CR) saham syariah yang terdaftar di Jakarta Islamic Index adalah sebesar 2,27 sehingga jika dibandingkan dengan standar tersebut, Current Ratio (CR) saham syariah ini bernilai baik.

\section{Perkembangan Earning Per Share (EPS)} Saham Syariah.

Tandelilin (2007) mendefinisikan Earning per share (EPS) sebagai perbandingan antara jumlah laba bersih dengan jumlah saham yang beredar. Sedangkan menurut Darmaji dan Fakhruddin (2006) mendefinisikan Earning per share (EPS) sebagai rasio yang menunjukan pembagian laba untuk setiap lembar saham Grafik 4.4 berikut memuat perkembangan EPS saham syariah selama tahun 2009 - 2016 .

Grafik 4.4

Perkembangan Earning per share (EPS)

Saham Syariah yang terdaftar di Jakarta Islamic Index Periode 2009-2016. 


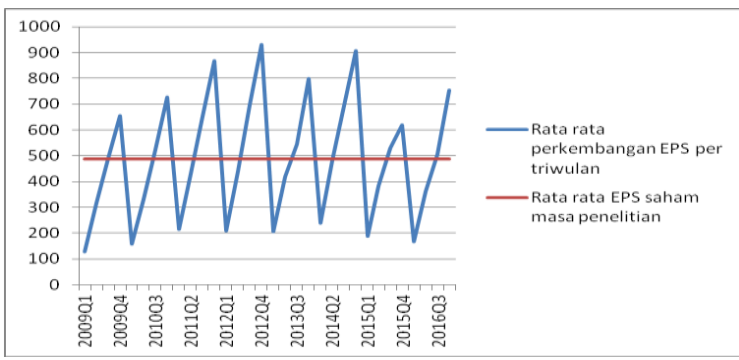

Sumber : Laporan Keuangan Publikasi, Data Diolah (2017)

Grafik 4.4 diperoleh informasi bahwa rata-rata EPS saham syariah tahun 2009-2016 adalah sebesar 486,30. EPS terendah dimiliki oleh emiten KLBF berada pada triwulan I tahun 2013 sebesar 10,00 dan EPS terbesar dimiliki oleh emiten UNTR pada triwulan IV tahun 2011 sebesar 1657. Perkembangan EPS emiten saham syariah selama tahun 2009-2016 cenderung berfluktuasi.

Menurut Lukviarman (2006) nilai rasio Earning per share (EPS) dikatakan baik jika mengalami peningkatan di setiap periode nya. Menurut Brigham dan Houston (2009) faktor-faktor pembentuk yang menyebabkan berfluktuasinya Earning Per Share (EPS) adalah laba bersih naik dan jumlah lembar saham biasa yang beredar tetap, laba bersih tetap dan jumlah lembar saham biasa yang beredar turun, laba bersih naik dan jumlah lembar saham biasa yang beredar turun, persentase kenaikan laba bersih lebih besar dari pada persentase kenaikan jumlah lembar saham biasa yang beredar, persentase penurunan jumlah lembar saham biasa yang beredar lebih besar dari pada persentase penurunan laba bersih. Sedangkan penurunan Earning Per Share (EPS) dapat dibentuk karena laba bersih tetap dan jumlah lembar saham biasa yang beredar naik, laba bersih turun dan jumlah lembar saham biasa yang beredar tetap, laba bersih turun dan jumlah lembar saham biasa yang beredar naik, persentase penurunan laba bersih lebih besar dari pada persentase penurunan jumlah lembar saham biasa yang beredar, persentase kenaikan jumlah lembar saham biasa yang beredar lebih besar dari pada persentase kenaikan laba bersih. Jadi bagi suatu perusahaan, nilai laba per saham akan meningkat apabila persentase kenaikan laba bersihnya lebih besar dari pada persentase kenaikan jumlah lembar saham biasa yang beredar,begitu pula sebaliknya.

\section{Perkembangan Total Asset Turn Over (TATO) Saham Syariah}

Brigham (2006) menyatakan bahwa Total asset turn over (TATO) adalah rasio aktifitas yang digunakan untuk mengukur seberapa besar efektifitas perusahaan dalam menggunakan sumber daya asset, rasio ini adalah rasio antara penjualan dengan total aktiva yang mengukur efisiensi penggunaan aktiva secara keseluruhan. Grafik 4.5 berikut memuat perkembangan TATO saham syariah selama tahun $2009-2016$.

Grafik 4.5

Perkembangan Total assets turn over (TATO) Saham Syariah yang terdaftar di Jakarta Islamic Index Periode 2009-2016

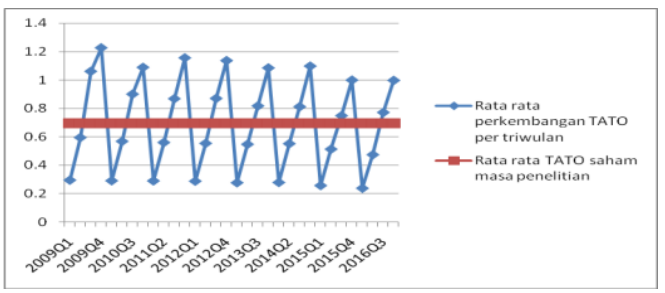

Sumber : Laporan Keuangan Publikasi, Data Diolah (2017)

Tabel 4.5 dan grafik 4.5 diperoleh informasi bahwa rata-rata TATO saham syariah tahun 2009-2016 adalah sebesar 0.70. TATO terendah dimiliki oleh emiten TLKM berada pada triwulan I tahun 2011 sebesar 0,11 dan terbesar dimiliki oleh emiten UNVR pada triwulan IV tahun 2009 sebesar 2,44. Perkembangan TATO emiten saham syariah selama tahun 2009-2016 cenderung berfluktuasi.

Menurut Lukviarman (2006) nilai Total assets turn over (TATO) dikatakan baik jika nilainya $>0.5$, jika dibandingkan dengan rata-rata Total assets turn over (TATO) saham syariah yang nilainya sebesar 0.70 maka nilai rasio Total assets turn over (TATO) pada saham syariah ini sudah baik. Nilai Total asset turn over (TATO) yang tinggi mengindikasikan 
bahwa manajemen perusahaan dapat mendayagunakan seluruh aktiva yang dimilikinya untuk mendatangkan revenue bagi perusahaan dengan peningkatan penjualan yang dihasilkan perusahaan, dengan demikian Total assets turn over (TATO) yang tinggi berpotensi menarik investor untuk berinvestasi di perusahaan tersebut dan akan meningkatkan nilai saham tersebut (Thrisye,2013).

Berfluktuasinya nilai Total assets

turn over (TATO) dibentuk oleh kemampuan perusahaan dalam menjual produk produk yang dihasilkan oleh perusahaannya. Penurunan Total assets turn over (TATO) dikarenakan nilai penjualan lebih kecil dari pada nilai total assets sedangkan peningkatan nilai Total assets turn over (TATO) di karenakan perusahaan dapat mengelola total aktiva dalam meningkatkan nilai penjualan perusahaan (Elita Ika, 2015).

\section{Perkembangan Return Saham Syariah} Return saham adalah tingkat keuntungan yang dinikmati oleh pemodal atas suatu investasi saham yang telah dilakukannya (Ang, 1997). Investasi jangka pendek maupun jangka panjang memiliki tujuan utama untuk memperoleh keuntungan yang disebut dengan return, baik langsung maupun tidak langsung (Ang, 1997). Return saham merupakan penghasilan yang diperoleh selama periode investasi per sejumlah dana yang diinvestasikan dalam bentuk saham (Bodie, 2011). Grafik 4.6 gambaran mengenai perkembangan return saham syariah yang terdaftar di Jakarta Islamic Index periode 2009-2016.

Grafik 4.6

Perkembangan Rata Rata Return saham syariah yang terdaftar di Jakarta Islamic Index Periode 2009-2016.

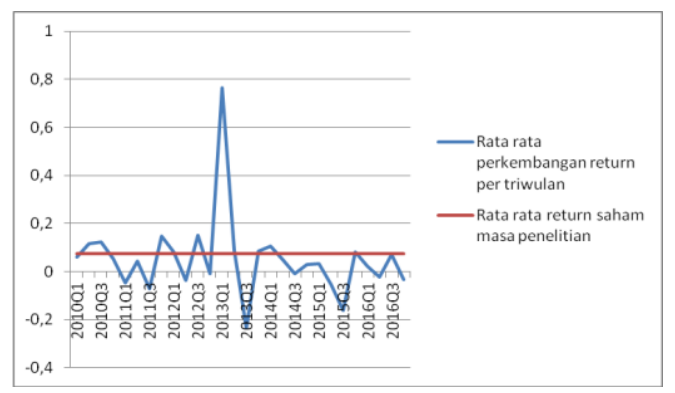

Sumber : Laporan Keuangan Publikasi, Data Diolah (2017)

Grafik 4.6 dapat diperoleh informasi bahwa rata-rata perkembangan return saham selama Tahun 2009 - 2016 adalah sebesar $7,47 \%$. Return saham terendah dimiliki oleh emiten TLKM yang berada pada Triwulan III Tahun 2013 yakni sebesar -0,8133. Return saham tertinggi dimiliki oleh emiten TLKM pada Triwulan I Tahun 2013 sebesar 5.0773. Kondisi perkembangan return saham syariah cenderung berfluktuasi.

Jika dilihat dari nilai perkembangan return saham selama Tahun 2009 - 2016 hanya sebesar 0,0747 atau $7.47 \%$. Investor mungkin akan membandingkan nilai return saham tersebut dengan nilai equivalent rate bagi hasil jika berinvestasi di bank syariah dengan bentuk tabungan, deposito atau giro. Berdasarkan Informasi dari Statistik Perbankan Syariah nilai rata rata nilai equivalent rate bagi hasil di bank syariah untuk periode 2009 sampai dengan 2016 adalah $9,41 \%$. Sehingga jika dibandingkan maka investor akan lebih besar memperoleh keuntungan jika berinvestasi di bank syariah dari pada berinvestasi di saham syariah.

\section{Pengujian Model pada Panel Data}

Pengujian model panel data pada dasarnya data panel memiliki tiga bentuk yaitu pooled, fixed effect dan random effect. Untuk memilih metode yang akan digunakan perlu dilakukan 2 (dua) uji. Pertama adalah uji chow dengan rendundant test. Uji ini dilakukan untuk memilih metode regresi panel data dengan pooled atau fixed effect. Apabila hasil uji chow menunjukkan model terbaik untuk digunakan adalah pooled, maka langkah selanjutnya adalah melakukan regresi dengan metode pooled least square dan tidak perlu melakukan uji kedua. Namun apabila hasil uji chow menunjukkan bahwa model terbaik yang dapat digunakan adalah fixed effect maka perlu dilakukan uji hausman. Uji hausman ini dilakukan untuk memilih metode fixed effect atau random effect. 
Hipotesis untuk melakukan uji chow adalah sebagai berikut.

- $\mathrm{H}_{0} \quad$ : Common effect model atau pooled least square

- $\mathrm{H}_{1} \quad$ : Fixed effect model

Cara melakukan uji chow adalah dengan membandingkan prob dari cross section chi square dengan tingkat signifikansi atau . Kriteria pengujiannya adalah sebagai berikut.

- Prob $<\alpha(0,05)$ : Tolak $\mathrm{H}_{0}$

- Prob $>\alpha(0,05)$ : Terima $\mathrm{H}_{0}$

Tabel 4.1 Tabel Uii Chow

Redundant Fixed Effects Tests
Pool: POOL01
\begin{tabular}{llll} 
Test cross-section fixed effects & & \\
\hline \hline & & & \\
Effects Test & Statistic & \multicolumn{1}{l}{ df } & Prob. \\
Cross-section F & 0.939561 & $(223.86)$ & 0.6415 \\
Cross-section Chi-square & 46.837914 & 223 & 0.1921 \\
& & & \\
\hline
\end{tabular}

Tabel 4.7 menunjukkan bahwa prob dari cross section chi square lebih besar dari $\alpha$ sebesar 0,05. Hasil ini menunjukkan bahwa model penelitian ini selanjutnya akan diregresikan menggunakan metode pooled least square atau common effect model dan uji hausman tidak perlu dilakukan.

Uji asumsi klasik yang dilakukan oleh penulis dalam penelitian ini adalah sebagai berikut:

\section{Uji Normalitas}

Uji normalitas dapat dilihat pada grafik dalam berikut :

Grafik 4.7

Grafik Normal P-Plot

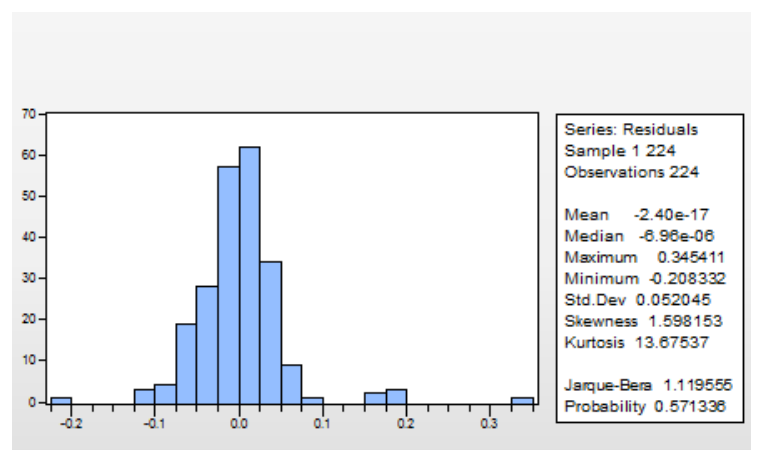

Grafik 4.7 di atas, dapat dilihat bahwa nilai prob Jarque-Bera adalah sebesar 0.571336 (>0.05) maka atas hal ini dapat disimpulkan bahwa residual terdistribusi normal.

\section{Uji Multikolinearitas}

Hasil uji multikolinearitas dapat dilihat pada tabel Coefficients seperti dalam Tabel 4.2 :

Tabel 4.8 Tabel Coefficients uji multikolinearitas

\begin{tabular}{|c|c|c|c|}
\hline Variable & $\begin{array}{l}\text { Coefficient } \\
\text { Variance }\end{array}$ & $\begin{array}{c}\text { Uncentered } \\
\text { VIF }\end{array}$ & $\begin{array}{c}\text { Centered } \\
\text { VIF }\end{array}$ \\
\hline $\mathrm{X} 1$ & 0.000101 & 1.203594 & 1.006755 \\
\hline$X 2$ & $6.67 \mathrm{E}-05$ & 3.800671 & 1.807080 \\
\hline$X 3$ & $6.04 \mathrm{E}-06$ & 3.989040 & 1.468849 \\
\hline $\mathrm{X} 4$ & $8.78 \mathrm{E}-11$ & 2.792568 & 1.113403 \\
\hline$\times 5$ & $6.71 \mathrm{E}-05$ & 3.947236 & 1.328149 \\
\hline C & 0.000127 & 10.29901 & NA \\
\hline
\end{tabular}

Tabel 4.2 di atas, menunjukan nilai Variance Inflation Factor (VIF) atas keseluruhan variabel berada dibawah angka 5 (lima), sehingga dapat disimpulkan tidak terjadi multikolinearitas antar variabel penelitian.

\section{Uji Autokorelasi}

Uji autokorelasi dapat dilihat pada tabel Model Summary seperti dalam Tabel 4.3

Tabel 4.3

Model Summary Uji Autokorelasi

\begin{tabular}{|c|c|c|c|c|}
\hline \multicolumn{5}{|c|}{$\begin{array}{l}\text { Dependent Variable: } Y \\
\text { Method: Least Squares } \\
\text { Date: } 10 / 23 / 17 \text { Time: } 15: 19 \\
\text { Sample: } 1224 \\
\text { Included observations: } 224\end{array}$} \\
\hline Variable & Coefficient & Std. Error & t-Statistic & Prob. \\
\hline$x_{1}$ & 0.002280 & 0.010059 & 2.226709 & 0.0209 \\
\hline X2 & -0.012940 & 0.008169 & 1.584112 & 0.1146 \\
\hline X3 & 0.005748 & 0.002458 & 2.338478 & 0.0203 \\
\hline$X 4$ & $2.53 \mathrm{E}-05$ & $9.37 \mathrm{E}-06$ & 2.703112 & 0.0074 \\
\hline$\times 5$ & 0.153615 & 0.008189 & 18.75788 & 0.0000 \\
\hline C & -0.018080 & 0.011287 & 2.601864 & 0.0106 \\
\hline R-squared & 0.704306 & \multicolumn{2}{|c|}{ Mean dependent var } & 0.074659 \\
\hline Adjusted R-squared & 0.697524 & \multicolumn{2}{|c|}{ S.D. dependent var } & 0.095710 \\
\hline S.E. of regression & 0.052638 & \multicolumn{2}{|c|}{ Akaike info criterion } & -3.024326 \\
\hline Sum squared resid & 0.604032 & \multicolumn{2}{|c|}{ Schwarz criterion } & -2.932943 \\
\hline Log likelihood & 344.7245 & \multicolumn{2}{|c|}{ Hannan-Quinn criter. } & -2.987439 \\
\hline F-statistic & 103.8497 & \multicolumn{2}{|c|}{ Durbin-Watson stat } & 2.080366 \\
\hline
\end{tabular}


Tabel 4.3 di atas, menunjukan nilai Statistik Durbin Watson (DW) data penelitian adalah sebesar 2,080366. Data ini menggunakan tabel Durbin Watson, untuk jumlah data $(\mathrm{n}=224)$ dan jumlah variabel (k) yang digunakan sebanyak 5 buah dengan $\alpha=5 \%$, maka diperoleh nilai statistik Durbin Watson sebagai berikut.

DU $=1,8199$

4-DU $=2,1801$

Sehingga dapat diperoleh hasil bahwa nilai DW berada diantara nilai DU dan 4-DU $(1,8199<2,080366<2,1801)$ maka dapat disimpulkan tidak terjadi autokorelasi.

\section{Uji Heteroskedastisitas}

Deteksi adanya heterokedastisitas dapat menggunakan uji glejser dengan hasil seperti dalam Tabel 4.4. Uji heteroskedastisitas dapat dilihat pada table uji glejser.

Tabel 4.4

Uji Glejser

Heteroskedasticity Test: Glejser

\begin{tabular}{llll}
\hline \hline F-statistic & 12.50874 & Prob. F(5,218) & 0.2046 \\
ObsR-squared & 49.93798 & Prob. Chi-Square(5) & 0.6122 \\
Scaled explained SS & 76.16232 & Prob. Chi-Square(5) & 0.4012 \\
\hline \hline
\end{tabular}

Tabel 4.4 di atas menunjukan bahwa nilai Prob F-statistic adalah sebesar 0.2046 yang lebih besar dari tingkat $\alpha$ sebesar 0.05 , sehingga dapat disimpulkan tidak terjadi heteroskedastisitas pada data penelitian.

Dari perhitungan perkembangan variabel penelitian selama tahun 2008-2016 diperoleh hasil bahwa perkembangan setiap variabel berfluktuatif. Dengan menggunakan uji chow diperoleh hasil bahwa model regresi yang cocok adalah model common effect. Model regresi common effect yang diperoleh adalah sebagai berikut.

Tabel 4.5 Model Summary Koefisien Variabel

Dependent Variable: $Y$

Method: Least Squares

Date: 10/23/17 Time: $15: 19$

Sample: 1224

Included observations: 224

\begin{tabular}{ccccc}
\hline \hline Variable & Coefficient & Std. Error & t-Statistic & Prob. \\
\hline \hline X1 & 0.002280 & 0.010059 & 2.226709 & 0.0209 \\
X2 & -0.012940 & 0.008169 & 1.584112 & 0.1146 \\
X3 & 0.005748 & 0.002458 & 2.338478 & 0.0203 \\
X4 & $2.53 \mathrm{E}-05$ & $9.37 \mathrm{E}-06$ & 2.703112 & 0.0074 \\
X5 & 0.153615 & 0.008189 & 18.75788 & 0.0000 \\
C & 0.018080 & 0.011287 & 2.601864 & 0.0106 \\
\hline
\end{tabular}

$\mathrm{Y}=0.00228 \mathrm{X}_{1}-0.01294 \mathrm{X}_{2}+$

$0.005748 X_{3}+2.53 E-05 X_{4}+0.153615 X_{5}$ $-0.01808+\mathrm{e}$

Pengaruh antar variabel penelitian, dapat diketahui melalui koefisien yang diperoleh dari estimasi parameter yang dimuat dalam Tabel 2. Besar pengaruh antara beberapa variabel dijelaskan dalam beberapa poin berikut.

1. Koefisien variabel ROA $\left(\mathrm{X}_{1}\right)$ adalah sebesar 0,00228 dengan prob sebesar $0.0209(<0.05)$ Koefisien positif menunjukkan bahwa pengaruh antara variabel ROA dan Return saham adalah berpengaruh positif. Artinya jika variabel ROA $\left(\mathrm{X}_{1}\right)$ meningkat maka variabel Return saham (Y) akan meningkat pula.

2. Koefisien variabel DER $\left(\mathrm{X}_{2}\right)$ adalah sebesar -0.012940 dengan prob sebesar 0.1146 $(>0.05)$. Koefisien negatif menunjukkan bahwa pengaruh antara variabel DER dan Return saham adalah berpengaruh negatif. Dengan nilai prob sebesar $0.1146(>0.05)$ artinya variable $\mathrm{X} 2$ tidak berpengaruh. Artinya jika variabel DER $\left(\mathrm{X}_{2}\right)$ meningkat maka variabel Return saham (Y) akan menurun.

3. Koefisien variabel $\mathrm{CR}\left(\mathrm{X}_{3}\right)$ adalah sebesar 0,005748 dengan prob sebesar 0.0203 $(<0.05)$. Koefisien positif menunjukkan bahwa pengaruh antara variabel $\mathrm{CR}$ dan Return saham adalah berpengaruh positif. Artinya jika variabel $\mathrm{CR}\left(\mathrm{X}_{3}\right)$ meningkat maka variabel Return saham (Y) akan meningkat pula.

4. Koefisien variabel EPS $\left(\mathrm{X}_{4}\right)$ adalah sebesar 2.53E-05 dengan prob sebesar 0.0074 $(<0.05)$. Koefisien positif menunjukkan bahwa pengaruh antara variabel EPS dan Return saham adalah berpengaruh positif. Artinya jika variabel EPS $\left(\mathrm{X}_{4}\right)$ meningkat maka variabel Return saham (Y) akan meningkat pula.

5. Koefisien variabel TATO $\left(\mathrm{X}_{5}\right)$ adalah sebesar 0,153615 dengan prob sebesar $0.0000 \quad(<0.05)$. Koefisien positif menunjukkan bahwa pengaruh antara variabel TATO dan Return saham adalah berpengaruh positif. Artinya jika variabel TATO $\left(\mathrm{X}_{5}\right)$ meningkat maka variabel Return saham (Y) akan meningkat pula. 


\section{Uji Hipotesis \\ Uji t}

Pengujian koefisien regresi secara parsial dilakukan melalui uji t. Hasil pengujian dapat dilihat dalam Tabel 2 diatas.

1. Nilai $t_{\text {hitung }}$ variabel ROA $\left(\mathrm{X}_{1}\right)$ adalah sebesar 2.226709 sedangkan nilai $\mathrm{t}_{\text {tabel}(0.025 ; 224-5-1)}$ adalah 1.97190 sehingga dapat disimpulkan secara parsial ROA $\left(\mathrm{X}_{1}\right)$ memiliki pengaruh positif terhadap Return Saham (Y).

2. Nilai $t_{\text {hitung }}$ variabel DER $\left(\mathrm{X}_{2}\right)$ adalah sebesar 1.584112 sedangkan nilai $\mathrm{t}_{\text {tabel(0.025:224-5-1) }}$ adalah 1.97190 sehingga dapat disimpulkan secara parsial DER $\left(\mathrm{X}_{2}\right)$ tidak memiliki pengaruh terhadap Return Saham (Y).

3. Nilai $t_{\text {hitung }}$ variabel $\mathrm{CR}\left(\mathrm{X}_{3}\right)$ adalah sebesar 2.338478 sedangkan nilai $t_{\text {tabel(0.025;224-5-1) }}$ adalah 1.97190 sehingga dapat disimpulkan secara parsial $\mathrm{CR}\left(\mathrm{X}_{3}\right)$ memiliki pengaruh positif terhadap Return Saham (Y).

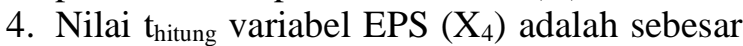
2.703112 sedangkan nilai $\mathrm{t}_{\text {tabel(0.025;224-5-1) }}$ adalah 1.97190 sehingga dapat disimpulkan secara parsial EPS $\left(\mathrm{X}_{4}\right)$ memiliki pengaruh positif terhadap Return Saham (Y).

5. Nilai $t_{\text {hitung }}$ variabel TATO $\left(X_{5}\right)$ adalah sebesar 18.75788 sedangkan nilai $\mathrm{t}_{\text {tabel}(0.025 ; 224-5-1)}$ adalah 1.97190 sehingga dapat disimpulkan secara parsial TATO $\left(\mathrm{X}_{5}\right)$ memiliki pengaruh positif terhadap Return Saham (Y).

Uji F

Uji $F$ atau uji koefisien regresi secara bersama-sama digunakan untuk mengetahui apakah secara bersama-sama variabel independen berpengaruh signifikan terhadap variabel dependen (Gujarati, 2009).

Hasil uji F dapat dilihat dalam Tabel

2. Dari tabel tersebut diperoleh :

1. Nilai $F_{\text {hitung }}$ (F-statistics) sebesar 103.8497;

2. Melalui Tabel Distribusi F diketahui bahwa nilai $\mathrm{F}_{\text {tabel }(5 ; 224-5)}=2.26$;

Dari poin 1 dan 2 diatas maka dapat diketahui bahwa nilai $F_{\text {hitung }}>F_{\text {tabel }}$ Sehingga dapat disimpulkan $\mathrm{H}_{0}$ ditolak dan $\mathrm{H}_{1}$ diterima. Dengan kata lain dapat disimpulkan bahwa secara simultan, terdapat pengaruh antara variabel Return on assets (ROA), Debt to equity ratio (DER), Current Rasio (CR), Earning per share (EPS), dan
Total assets turnover (TATO) terhadap Return Saham.

\section{Implikasi Manajerial}

Perkembangan variabel-variabel penelitian yang bersifat fluktuatif merupakan hal yang sangat mengkhawatirkan. Berdasarkan hasil penelitian berikut ini dipaparkan langkahlangkah yang dapat ditempuh untuk memberikan kontribusi praktis bagi perusahaan perusahaan yang tergabung dalam Jakarta Islamic Index dalam usaha meningkatkan return saham syariah pada periode-periode berikutnya.

Pemetaan strategi dilakukan berdasarkan variabel-variabel solusi yang diperoleh dari hasil penelitian. Pemetaan startegi dapat dijelaskan pada berikut:

Peta Strategi Peningkatan Return Saham

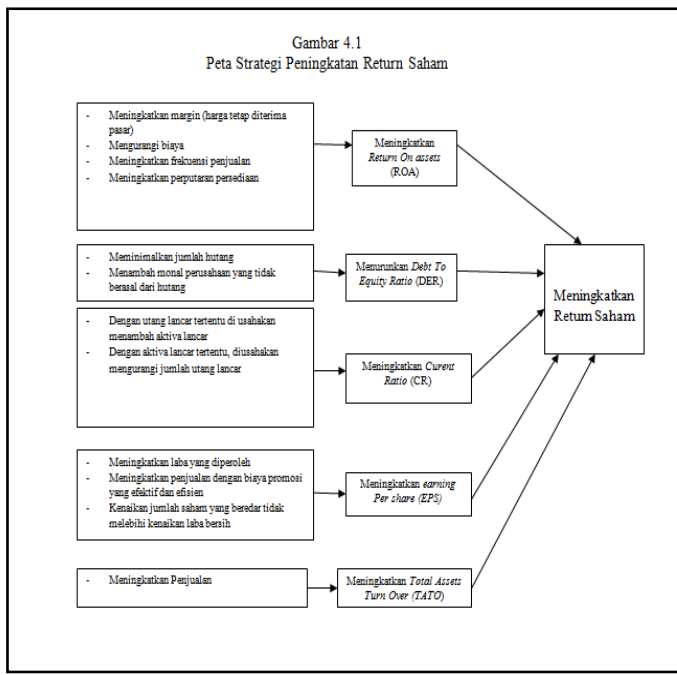

Para pemimpin perusahaan yang tergabung dalam Jakarta Islamic Index memerlukan pedoman yang logis untuk membangun strategi yang mumpuni dalam meningkatkan nilai return sahamnya. Pedoman tersebut dapat diperoleh dengan cara mengoperasionalisasikan strategi yang telah dipetakan berdasarkan hasil penelitian.

Prinsipnya operasionalisasi strategi tersebut harus memperhatikan besarnya pengaruh Return on assets (ROA), Debt to equity ratio (DER), Current Rasio (CR), Earning per share (EPS), dan Total assets turnover (TATO) terhadap Return saham. Jika pemilihan atau penggunaan variabel 
tersebut relevan dengan tujuan pengambilan keputusan manajemen maka keputusan yang akan diambil akurat pada akhirnya berdampak pada peningkatan Return saham. Berdasarkan operasionalisasi variabel, agar tujuan perusahaan tercapai maka diperlukan rencana tindakan untuk setiap variabel sebagai berikut :

Rencana Tindakan Indikator/Variabel Berpengaruh/Pemecah Masalah

\begin{tabular}{|c|c|c|}
\hline No. & Variabel & Rencana / Tindakan \\
\hline 1 & $\begin{array}{l}\text { Return } \\
\text { on } \\
\text { assets } \\
\text { (ROA) }\end{array}$ & 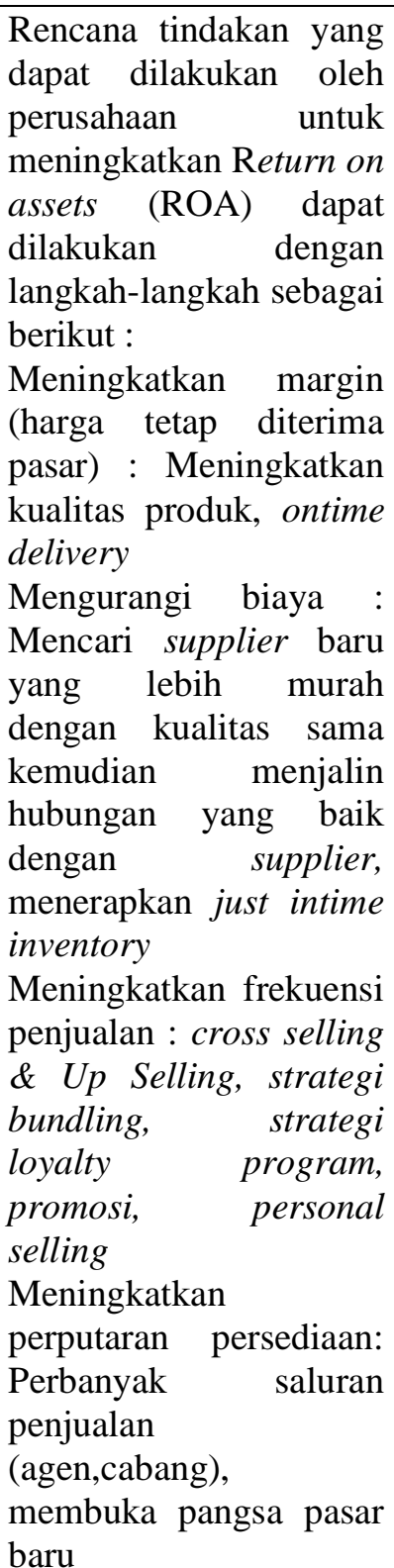 \\
\hline
\end{tabular}

\begin{tabular}{|c|c|c|}
\hline 2 & $\begin{array}{l}\text { Debt to } \\
\text { equity } \\
\text { ratio } \\
\text { (DER) }\end{array}$ & $\begin{array}{l}\text { Rencana tindakan yang } \\
\text { dapat dilakukan oleh } \\
\text { perusahaan untuk } \\
\text { menurunkan Debt to } \\
\text { equity ratio (DER) } \\
\text { dapat dilakukan dengan } \\
\text { langkah-langkah sebagai } \\
\text { berikut : } \\
\text { Meminimalkan jumlah } \\
\text { hutang : Pelunasan } \\
\text { hutang jangka pendek } \\
\text { sebelum jatuh tempo } \\
\text { Menambah modal } \\
\text { perusahaan yang tidak } \\
\text { berasal dari hutang: } \\
\text { Para pemilik perusahaan } \\
\text { menambah jumlah } \\
\text { modal yang di } \\
\text { investasikan pada } \\
\text { perusahaannya, } \\
\text { menerbitkan saham baru }\end{array}$ \\
\hline 3 & $\begin{array}{l}\text { Current } \\
\text { Rasio } \\
\text { (CR) }\end{array}$ & 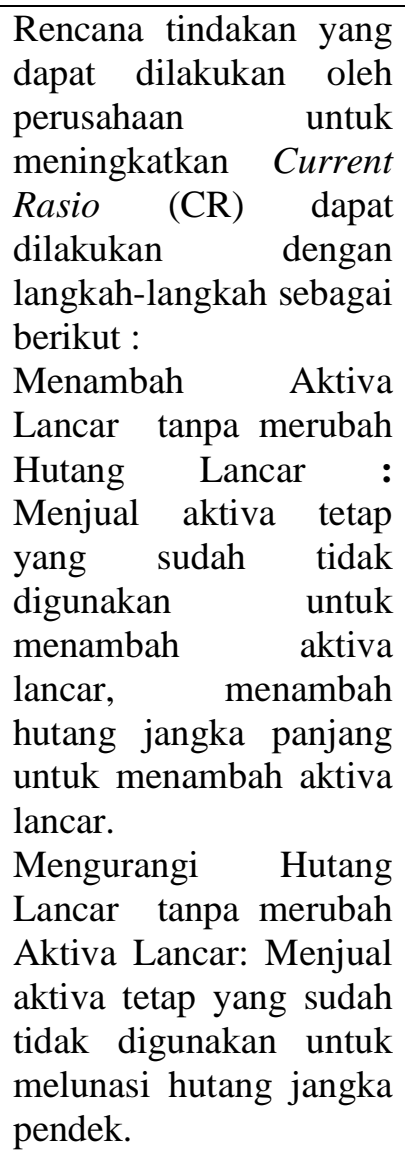 \\
\hline 4 & $\begin{array}{l}\text { Earning } \\
\text { per } \\
\text { share } \\
\text { (EPS) }\end{array}$ & $\begin{array}{lr}\text { Rencana tindakan yang } \\
\text { dapat dilakukan } & \text { oleh } \\
\text { perusahaan } & \text { untuk } \\
\text { meningkatkan } & \text { Earning }\end{array}$ \\
\hline
\end{tabular}




\begin{tabular}{|c|c|c|}
\hline & & $\begin{array}{l}\text { per share (EPS) dapat } \\
\text { dilakukan dengan } \\
\text { langkah-langkah sebagai } \\
\text { berikut: } \\
\text { Kenaikan jumlah saham } \\
\text { yang beredar tidak } \\
\text { melebihi kenaikan laba } \\
\text { bersih: jumlah } \\
\text { penerbitan saham baru } \\
\text { disesuaikan dengan } \\
\text { persentasi kenaikan laba } \\
\text { bersih. }\end{array}$ \\
\hline 5 & $\begin{array}{l}\text { Total } \\
\text { assets } \\
\text { turnover } \\
\text { (TATO) }\end{array}$ & $\begin{array}{l}\text { Rencana tindakan yang } \\
\text { dapat dilakukan oleh } \\
\text { perusahaan } \\
\text { meningkatkan } \quad \text { Total } \\
\text { assets turnover (TATO) } \\
\text { dapat dilakukan dengan } \\
\text { langkah-langkah sebagai } \\
\text { berikut: } \\
\text { Diusahakan } \\
\text { peningkatan total assets } \\
\text { tidak } \\
\text { peningkatan jelebihi } \\
\text { penjualan. jumlah }\end{array}$ \\
\hline
\end{tabular}

Penyusunan program lebih lanjut perlu dilakukan agar rencana tindakan yang telah diuraikan dapat direalisasikan. Program-program yang disusun sebaiknya lebih banyak mengarah kepada kondisi masing masing perusahaan yang tergabung dalam Jakarta Islamic index . Rencana tindakan tersebut diharapkan dapat meningkatkan kualitas Return on assets (ROA), Debt to equity ratio (DER), Current Rasio (CR), Earning per share (EPS), dan Total assets turnover (TATO) dengan peningkatan return saham Dengan demikian perusahaan yang tergabung dalam Jakarta Islamic index memiliki nilai return yang menarik bagi para investor.

\section{KESIMPULAN DAN SARAN \\ Kesimpulan}

Adapun kesimpulan yang dapat diberikan sehubungan dengan hasil penelitian dan pembahasan ini adalah sebagai berikut:

1. Return on asset (ROA) berpengaruh positif terhadap return saham artinya variasi nilai Return on asset (ROA) dapat menjelaskan variasi nilai return saham.

2. Debt to equity ratio (DER) tidak berpengaruh terhadap Return Saham artinya Debt to equity ratio (DER) tidak mampu menjelaskan variasi nilai return saham.

3. Current ratio (CR) berpengaruh positif terhadap Return Saham artinya variasi nilai Current ratio (CR) dapat menjelaskan variasi nilai return saham.

4. Earning per share (EPS) berpengaruh positif terhadap Return Saham artinya variasi nilai Earning per share (EPS) dapat menjelaskan variasi nilai return saham.

5. Total asset turn over (TATO) berpengaruh positif terhadap Return Saham artinya variasi nilai Total asset turn over (TATO) dapat menjelaskan variasi nilai return saham.

6. Return on asset (ROA), Debt to equity ratio (DER), Current ratio (CR), Earning per share (EPS), dan Total asset turn over (TATO) secara simultan berpengaruh terhadap return saham artinya variasi nilai Return on asset (ROA), Debt to equity ratio (DER), Current ratio (CR), Earning per share (EPS), dan Total asset turn over (TATO) dapat menjelaskan variasi nilai return saham.

\section{Saran}

Adapun saran yang dapat dijadikan masukan dan bahan pertimbangan yang berguna bagi pihak-pihak yang berkepentingan, antara lain sebagai berikut :

1. Para manajer perusahaan yang tergabung dalam Jakarta Islamic Index memerlukan pedoman yang logis untuk membangun suatu strategi yang memadai yang pada akhirnya diharapkan mampu meningkatkan return saham, maka disarankan dapat dilakukan dengan cara mengoperasionalisasikan strategi yang telah dipetakan berdasarkan hasil penelitian.

2. Berpengaruhnya Return on asset (ROA), Debt to equity ratio (DER), Current ratio (CR), Earning per share (EPS), dan Total asset turn over (TATO) terhadap return saham yang positif, maka dapat menjadi bahan pertimbangan pihak manajemen perusahaan pemilik emiten saham syariah tersebut untuk senantiasa meningkatkan 
variabel-variabel tersebut guna menarik investor untuk berinvestasi dalam bentuk saham yang dikeluarkan oleh perusahaan.

3. Bagi investor yang akan berinvestasi dipasar modal khususnya di Jakarta Islamic Index sebaiknya mempertimbangakan faktor faktor fundamental karena berdasarkan beberapa penelitian yang dilakukan variabel variabel tersebut berpengaruh terhadap return saham.

4. Bagi peneliti selanjutnya, dapat melakukan penelitian selain Return on asset (ROA), Debt to equity ratio (DER), Current ratio (CR), Earning per share (EPS), dan Total asset turn over (TATO) dengan return saham secara parsial dengan metode yang berbeda dan juga mengkaji faktor-faktor lainnya yang turut mempengaruhi profitabilitas.

\section{DAFTAR PUSTAKA}

Ang, Robert.(1997).Buku Pintar Pasar Modal Indonesia.Jakarta:Media Staff Indonesia

Arisandi, Meri, (2014). Pengaruh ROA, DER, CR, Inflasi dan Kurs Terhadap Return Saham (Studi Kasus Industri Makanan dan Minuman Yang Terdaftar di BEI Periode 2008-2012). Jurnal Dinamika Manajemen Vol.2 No.1 ISSN: 2355-8148.Hal: 34-46

Ahmad, Kamaruddin. (2004). Dasar-dasar Manajemen Investasi. Edisi Revisi. Jakarta: Rineka Cipta.

Aisyah Husna Zulkarnaen, Muhamad Syamsun, Tb Nur Ahmad Maulana. (2016). Analysis of fundamental an technical factors to stock price on residential property sector companies listed in Indonesia stock exchange. International journal of scientific and research publication. Volume 6 ISSN 2250-3153

Agus Widarjono. (2009). Ekonometrika Pengantar dan Aplikasinya. Edisi Ketiga. EKONISIA. Yogyakarta.

Baltagi, Badi H., (2005). Econometric Analysis of Panel Data. 3rd Ed. West Sussex: John Wiley and Sons Ltd.
Bambang sudarsono dan Bambang Sudiyatno. (2016). Faktor Faktor yang mempengaruhi Return Saham Pada Perusahaan Poperti dan Real estate yang terdaftar pada bursa efek Indonesia. Jurnal bisnis dan ekonomi maret 2016 hal 30-51. ISSN 1412-3126

ChuzaimahdanNur Amalina. Analis Pengaruh Faktor Faktor Fundamental Terhadap Return Saham Syariah Pada Perusahaan yang tergabung dalam Jakarta Islamic Index (JII) Tahun 20072011.2014. Seminar nasional and call paper (Sancall 2014) isbn :978602-70429-1-9

ChuzaimahdanNur Amalina. Analis Pengaruh Faktor Faktor Fundamental Terhadap Return Saham Syariah Pada Perusahaan yang tergabung dalam Jakarta Islamic Index (JII) Tahun 20072011.2014. Seminar nasional and call paper (Sancall 2014) isbn :978602-70429-1-9

Damodar N. Gujarati and Dawn C. Porter. 2012. Dasar-dasar Ekonometrika. Jakarta: Salemba Empat

Eljelly, M. Abuzar and Khalid S Alghurair. (2001). Performance measures and wealth creation in an emerging market : the case of Saudi Arabia. International journal of commerce and management.

Eduardus Tandelilin. (2007). Analisis Investasi dan Manajemen. Portofolio (Edisi Pertama, Cetakan Kedua). Yogyakarta: BPFE

Eungene F. Brigham dan Joel F. Houaton,(2001), Manajemen Keuangan, Erlangga, Jakarta,

Emzir, (2009), Metodologi Penelitian Pendidikan, Kuantitatif dan Kualitatif,Jakarta :Raja Grafindo Persada

Ganesh,L., Venkates,C.K., Madhu,T.(2012). Fundamental analysis and stock return:an Indian Evidence. Journal of economics, accounting and 
finance Vol.1 (2) pp. 033-039, Desember 2012

Gulnur Maragdoglu. (2008). “An Empirical Tes on Leverage and Stock Return". Cash Business School. London International Jurnal

Gantyowati, Evi dan Arwanta, Erwin, (2004), "Kemampuan Prediksi Rasio Keuangan Terhadap Harga Saham",Kajian Bisnis, Vol.12, No. 1

Gitman, L. J.\& Joehnk, M. D. (1996). Fundamental of Investing , Sixth Edition, Harper Collins College Publishers, New York

Gujarati, Damodar, (1999),Ekonometrika Dasar, Erlangga, Jakarta

Ghozali, Imam. (2011).Aplikasi Analisis Multivariate Dengan Program SPSS.Semarang: Badan Penerbit Universitas Diponegoro.

Hartono, Jogiyanto. (2014). Teori Portofolio dan Analisis Investasi, Edisi Kedelapan. Yogyakarta: BPFE

Harries Hidayat dan Hakinus Manao. (2000). “ Asosiasi Laba Tahunan Emiten dengan Harga Saham Ditinjau dari Ukuran da Debt-Equity Ratio Perusahaan. Simposium Nasional Akuntansi III: Ikatan Akuntan Indonesia - Kompartemen Akuntan Pendidik. September: 522536.

Juanita Bias Dwialesi. (2016). Pengaruh factor factor Funfamental terhadap return saham indeks kompas 100. Jurnal Manajemen Unud Vol 5 No.24 ISSN 2302-8912

Kasmir. (2012). Analisis Laporan Keuangan.Jakarta: Rajawali Pers.

Murtanto dan Harkivent. (2000). "Analisis

Pengaruh Infromasi Laba", Jurnal

Ekonomi, Vol.6 No.3, hal. 992-1021

Mamduh M. Hanafi dan Abdul Halim,(2003),“Analisis Laporan Keuangan”,AMP-YKPN, Yogyakarta.

Sabalno. (2010). Analisis Pengaruh Faktor Fundamental dan Kondisi Ekonomi Terhadap Return Saham (Studi Kasus Pada Perusahaan Otomotif dan Komponen Yang Listed di Bursa Efek Indonesia Periode 20032007). ORBITH, Vol. 6, No. 1, Maret 2010.

Suad Husnan. (2001). Pembelajaran Perusahaan (Dasar-Dasar Manajemen Keuangan). Edisi Ketiga. Liberty, Yogyakarta.

Sugiyono.(2010). Metode Penelitian Kuantitatif Kualitatif \& RND. Bandung : Alfabeta

Sugiharti, Surahman, Siti Aisjah. (2015). Pengaruh kinerja keuangan perusahaan terhadap return saham. Jurnal Aplikasi Manajemen Vol 13 No. 22015

Syamsudin, Lukman, (2004). Manajemen Keuangan, Penerbit Raja Grafindo Persada, Jakarta

Suharli, Michell. (2004). Audit Finansial, Audit Manajemen dan Sistem Pengendalian Intern .

Ulupui. (2005) "Analisis Pengaruh Rasio Likuiditas, Leverage, Aktivitas, dan Profitabilitas terhadap return saham (Studi Pada Perusahaan Makanan dan Minuman dengan Kategori Industri Barang Konsumsi di BEJ)", Fakultas Ekonomi Universitas Udayana, 2005.

Ulupui, (2009). Pengaruh Analisis Pengaruh Rasio Likuiditas, Leverage, Aktivitas, dan Profitabilitas Terhadap Return Saham (Studi pada perusahaan makanan dan minuman di BEJ), Skripsi,Jurusan Akuntansi, Fakultas Ekonomi, Universitas Udayana.

Van Horne, James C. and John M. Wachowicz. (2007). Fundamentals of Financial Management, PrinsipPrinsip Manajemen Keuangan . Jakarta : Salemba Empat

Yeye Susilowati. (2006). Konsekuensi Signal Subtitusi dan Komplemen Dalam Keputusan Keputusan Pendanaan. Disertasi. Program Doktor Ilmu Ekonomi. Universitas Gadjah Mada. Yogyakarta

Yeye susilowati. (2011). Reaksi signal rasio profitabilitas dan rasio solvabilitas 
terhadap return saham perusahaan. Jurnal Dunamika keuangan dan perbankan mei 2011 hal 17-37. Issn 1979-4878.

https://www.kompasiana.com/fajarkurnia/6hal-perbedaan-pasar-modalkonvensional-dan-pasar-modalsyariah_58bea9b0a3afbde416b3a1d $\underline{0}$ 